\title{
JILBAB: BUDAYA POP DAN IDENTITAS MUSLIM DI INDONESIA
}

\author{
Lina Meilinawati Rahayu \\ Universitas Padjadjaran \\ Jl. Raya Bandung Sumedang Km. 21, Jatinangor, Jawa Barat \\ Email: lina_sastraunpad@yahoo.co.id
}

Abstract: The purpose of this study is to examine jilbab as a pop culture and Indonesian moslem identity. The use of jilbab (a headscarf or a head covering) for moslem women has gained its popularity since the last twenty year. This phenomenon is interesting to be investigated particularly from diverse jilbab or veiling practices in many different ways. Indonesian moslem women, for instance, used styles of jilbab and fashion which are different from those worn by moslem women in other countries. Hence, this shows characteristics of Indonesian moslem women in wearing or using jilbab which becomes an identity. Many scholars see identity as a product of social construction, and a fluid concept. This is due to the emergence of various identities resulted from different contexts. For the theoretical framework, this study uses Barthes semiotic analysis to interpret and decode the signs attached to jilbab and Indonesian moslem fashion as a part of pop culture and a new identity. The result of the study indicates that jilbab as a headscarf changes from time to time in terms of its use and styles. Jilbab styles worn by Indonesian moslem women adopted both local and global styles. This demonstrates the hybrid identity of Indonesian moslem women in wearing or using jilbab.

Keywords: jilbab, pop culture, identity, Indonesian muslim, ambivalence.

Abstrak: Tulisan ini ingin meneliti jilbab sebagai budaya pop dan identitas muslim Indonesia. Pemakaian jilbab (penutup kepala) untuk para perempuan muslim amat marak terutama pada dua puluh tahun terakhir. Fenomena ini menarik untuk diperhatikan terutama dari segi tutup kepala dan busana yang model dan gayanya sangat beragam. Model jilbab dan busana yang digunakan para perempuan muslim Indonesia tidak sama bahkan berbeda dengan jilbab dan busana muslim perempuan di negara-negara Islam lainnya. Hal ini kemudian menjadi ciri khas muslim Indonesia dalam berjilbab yang telah membentuk identitas sendiri. Sebagaimana disepakati para ahli bahwa identitas merupakan konstruksi sosial merupakan konsep 
yang cair. Kecairan ini terutama disebabkan oleh kemungkinan munculnya ragam identitas yang bersifat kontekstual. Metode semiotik Barthes digunakan untuk memaknai tanda-tanda yang ada pada jilbab dan busana muslim Indonesia sebagai bagian dari budaya pop dan pembentuk identitas baru. Dari penelitian ini ditemukan bahwa jilbab sebagai penutup kepala bentuknya berubah-ubah sesuai dengan perkembangan trend. Model jilbab perempuan muslim di Indonesia mengadopsi berbagai gaya lokal dan global. Selain itu, penggunaan jilbab bernegosiasi dengan budaya setempat. Hal inilah yang menjadikan perempuan muslim Indonesia mempunyai identitas hibrid dalam berjilbab.

Kata Kunci: jilbab, budaya pop, identitas, muslim Indonesia, ambivalensi.

\section{A. Pendahuluan}

Pada tahun 80-an jilbab adalah sesuatu yang "tidak lazim" untuk perempuan di Indonesia. Masih segar dalam ingatan saya ketika SMP (1983) berbondong-bondong siswa pindahan datang dari SMP negeri ke sekolah yang membolehkan mereka memakai jilbab. Berhijrahnya mereka disebabkan sekolah umum melarang siswa perempuan berjilbab. Itu tahun 80 -an. Kondisi saat ini sungguh berbeda. Sekarang, sekolah negeri bahkan "mewajibkan" siswa perempuan berjilbab pada hari tertentu. ${ }^{1}$ Hal ini bermula dari berubahnya sikap rezim Soeharto terhadap Islam pada akhir tahun 80-an. Heryanto (2012:19) menegaskan bahwa politik Islam menemukan momentum kebangkitannya pada tahun 90-an. Soeharto merangkul berbagai kelompok Islam, mencabut larangan berjilbab, ${ }^{2}$ jumlah mesjid mendadak berlipat, membatalkan pembatasan izin surat kabar baru, hingga munculnya organisasi Islam nasional ICMI (Ikatan cendikiawan Muslim Indonesia). Itulah awal "kebangkitan" Islam di Indonesia.

Kondisi ini memunculkan kelompok muslim "baru” yang kemudian oleh Ibrahim (2011:147) dijelaskan dengan maraknya segala sesuatu yang dikaitkan dengan identitas itu, misalnya iklan dan industri jasa yang menawarkan wisata religius, umroh bersama kiai terkenal, berdirinya sekolah-sekolah Islam yang mahal, kafe khusus muslim, menjamurnya konter-konter berlabel Exclusive Moslem Fashion, marak penerbitan majalah dan sastra Islam. Dalam hal ini Ibrahim sampai pada simpulan bahwa ada ideologi yang sedang ditanamkan, yaitu beragama tapi tetap trendi atau biar religius tapi tetap modis.

${ }^{1}$ Simpulan ini diambil berdasarkan pengamatan pada sekolah-sekolah di Jawa Barat, khususnya Kota Bandung.

${ }^{2}$ Larangan berjilbab di sekolah berdasarkan SK 052/1982. 
Dalam kurun waktu kurang lebih dua puluh tahun belakangan ini, pemakaian jilbab bukan hanya sangat banyak bahkan mewabah. Kondisi ini semakin diperkuat dengan bukti-bukti penelitian ilmiah yang telah banyak dilakukan. Salah satu skripsi yang ditulis Rima Hardiyanti (2012) dari Universitas Hasanudin Makasar berjudul "Komunitas Jilbab Kontemporer Hijabers di Kota Makasar". Dalam skripsinya Hardiyanti menjelaskan adanya komunitaskomunitas perempuan berjilbab yang umum disebut dengan istilah "Hijabers". ${ }^{3}$ Kelompok ini adalah kalangan menengah ke atas yang menjadikan kafe sebagai tempat nongkrong, memakai busana muslim trendi, dan menggunakan bahasa Indonesia, Arab, Inggris sebagai alat komunikasi. Satu lagi skripsi lagi ditulis oleh Elizabeth Raleigh (2004) dari Universitas Muhamadiyah Malang dengan judul "Busana Muslim dan Kebudayaan Populer di Indonesia: Pengaruh dan Persepsi”. Dalam pembahasannya Raleigh memaparkan bahwa pemakaian busana muslim semakin hari semakin banyak. Hal ini mendorong industri busana muslim menjadi sangat berkembang. Penelaahan difokuskan pada produksi, distribusi, dan konsumsi busana muslim. Selain juga, membincangkan beberapa perancang busana muslim di Indonesia.

Dalam tulisan ini pembahasan tentang jilbab akan difokuskan pada posisi jilbab dalam budaya populer Indonesia. Selain itu, menjelaskan faktor-faktor yang mempengaruhi model jilbab yang selalu berubah dari waktu ke waktu. Perubahan model disesuaikan dengan trend yang sedang berkembang. Dengan demikian, pembicaraan tentang jilbab ini tidak ada kaitannya dengan benar atau salah dalam penggunaannya. Fokus analisis pada identitas yang ditampilkan melalui penutup kepala tersebut dalam budaya populer di Indonesia.

\section{B. Jilbab dan Budaya Populer di Indonesia}

Heryanto (2012:8) memaparkan bahwa ada tiga alasan yang bisa dijadikan alasan langkanya analisis mendalam mengenai budaya pop di Indonesia. Pertama, budaya pop merupakan gejala yang masih baru di mata khalayak. Kedua, kuatnya paradigma tertentu dalam kajian sosial ini. Ketiga, kuatnya bias maskulin di dunia keilmuan kita secara umum. Penjelasan tentang ketiga hal tersebut diakhiri dengan simpulan bahwa apa saja yang kemudian dapat dijadikan objek penelitian dalam budaya populer. Heryanto menyetujui pendapat Strinati

${ }^{3}$ Hijabers adalah istilah yang muncul pada beberapa tahun belakangan ini. Yang dimaksudkan pada kelompok perempuan berjilbab, tapi tetap trendi. Oleh sebab itu, tren model jilbab diiringi pula dengan tutorial hijab yang mengajarkan langkah-langkah berjilbab dengan mengikuti tren yang sedang berkembang. 
(1995) bahwa istilah tersebut merujuk pada berbagai ragam tindak komunikatif yang beredar luas yang disajikan untuk sebagian besar rakyat "biasa" atau oleh rakyat, atau kombinasi keduanya. Mendudukkan jilbab dalam definisi di atas adalah kombinasi keduanya. Jilbab sekarang dikomodifikasi dan diproduksi massal. Jilbab juga merupakan tindak komunikatif yang relatif mandiri. Hal ini ditandai dari pemakaian jilbab yang sangat beragam sesuai dengan keinginan pemakainya. Jilbab juga menjadi alternatif at as gaya hidup.

Storey (2007) meyakinkan para peneliti kajian budaya bahwa wacana yang dijadikan objek penelitian terbentang luas (banyak dan beragam), yang merespons kondisi politik dan historis yang berubah dan selalu ditandai dengan perdebatan, ketidaksetujuan, dan intervensi. Dengan demikian, budaya dalam cultural studies didefinisikan secara politis daripada secara estetis, yaitu sebagai ranah pergumulan. Pemakaian jilbab di Indonesia adalah salah satu dari budaya berpakaian wanita muslim Indonesia (saat ini). Perkembangannya sangat dinamis, baik dari perubahan model atau jumlah pemakainya. Sudah dijelaskan di atas bahwa berjilbab mulai marak di akhir tahun 90-an dan kini boleh dikatakan puncaknya. Bila tahun 80 -an pengguna jilbab merupakan minoritas, sekarang mereka mayoritas. Penelitian tentang jilbab tidak bisa dilepaskan dari unsur politis karena di Indonesia pada tahun 80 -an pemerintah secara resmi melarang penggunaanya dalam aktivitas formal (sekolah, pegawai negeri). Kondisi ini menimbulkan pro dan kontra. Baik dari komunitas yang mempertahankan untuk tetap memakai dan kalangan yang bersikukuh mematuhi aturan. Persoalan pro dan kontra saat ini pun masih terus berlangsung. Perdebatan yang tak kunjung usai ini pun terjadi karena perbedaan cara pandang dalam pemakai-

\section{Gb. 3. Salah satu komunitas hijabers}

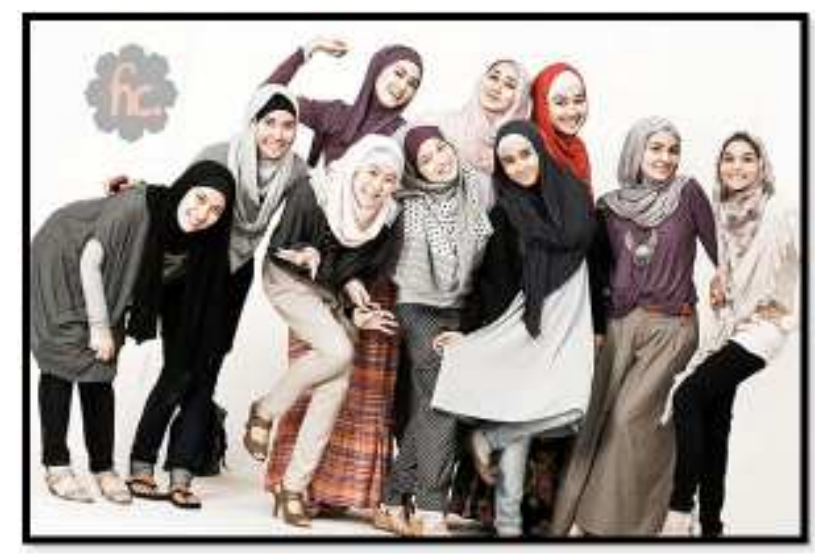

http:// Hijabers-Community-Jakarta-Indonesia.jpg 
annya. Selanjutnya, yang tak kalah penting adalah soal intervensi media yang mempengaruhi opini masyarakat.Opini dibentuk melalui berbagai tayangan religius. Bintang sinetron berjilbab, penyanyi berjilbab, pemenang ajang pencarian bakat berjilbab, dan lain-lain. Opini yang dibentuk, khususnya oleh televisi, seperti yang dikemukakan Ibrahim (2011) "beragama tapi tetap trendi atau biar religious tapi tetap modis".

Dalam hingar bingar beragam model busana dan gaya berbusana, begitu pun busana muslim.. Kondisi ini menimbulkan berbagai kekhawatiran dari sebagian orang yang menganggap pemakaian jilbab tersebut tidak sesuai syariat (hukum agama). Solichul (2006) menulis buku Jilbab Funky tapi Syar'i dengan gaya berbahasa anak muda. Dijelaskan bagaimana sebaiknya berjilbab yang sesuai syariat Islam.Namun, fokus pembicaraan bukan sekadar sesuai at uran atau tidak, penulis ingin menyampaikan bahwa berjilbab bisa tetap gaya tanpa menyalahi aturan. Dia menulis istilah "jilbab funky". Arti kata funky yang paling sesuai bila diterapkan dalam berbusana adalah stylish and modern in an unconventional way (http://artikata.com/arti-73530-funky.html) atau dalam pengertian "gaya dan modern dengan cara yang tidak biasa". Bila diterapkan pada cara berjilbab yang funky (dalam buku ini), ada delapan yang harus dipenuhi. Kedelapan syarat itu adalah; (1) harus menutupi badan, selain yang dikecualikan, (2) bukan sekadar hiasan, (3) berkain tebal, (4) tidak boleh "ngetat", (5) tidak diberi wewangian/ parfum berlebihan, (6) tidak menyerupai pakaian laki-laki, (7) tidak boleh sama dengan perempuan kafir, dan (8) bukan untuk mencari popularitas. Sayangnya, penulis tidak menunjukkan bahwa jilbab yang sesuai syariat, tetapi funky itu seperti apa. Apakah bila kedelapan syarat itu dipenuhi lalu dengan serta merta pemakai jilbab menjadi funky. Syarat yang nomor delapan, yaitu bukan mencari popularitas, bukanlah bagaimana berjilbab, melainkan niat menggunakan jilbab. Akan sangat sulit mengukur niat seseorang berjilbab, selain juga tidak ada kaitannya dengan berjilbab funky. Pandangan yang dikemukakan ini mengandung ambivalensi. Penulis memiliki asumsi awal bahwa memakai jilbab itu tidaklah funky, tapi berjilbab bisa menjadi funky dengan tetap mengikuti kedelapan syarat-syarat yang sudah disebutkan di atas. Pada akhirnya sulit untuk mengetahui jilbab yang tidak funky dan jilbab yang funky, tapi tetap syar'i itu seperti apa dan bagaimana dalam implementasinya.

Budaya populer yang disejajarkan dengan budaya massa identik dengan melimpahnya produksi. Munculnya kelompok Islam "baru" ini dan berkembangnya pemakaian jilbab mendorong peningkatan produksi. Yang dimaksud adalah melimpahnya industri busana muslim dan ini menjadi sasaran pasar yang 
menggiurkan, Ditambah lagi beberapa selibritas memproduksi busana-busana muslim dengan label namanya. Bisa dilihat di banyak mall, di pasar-pasar besar, di ruko-roko busana muslim dijajakan hingga mendominasi pasar. Misalnya di Pasar Tanah Abang Jakarta atau di Pasar Baru Bandung, busana muslim dan aneka perlengkapannya memenuhi hampir sebagian besar isi pasar. Untuk menarik konsumen diadakan juga demontrasi tutorial hijab yang diselenggarakan di mall-mall atau pasar-pasar besar. Tutorial hijab ini menjelaskan dan mempraktekkan langkah-langkah pemakaian jilbab yang sedang trend saat ini. Yang kemudian model yang sedang trend itu ramai-ramai diikuti oleh para hijabers.

\section{Gb. 4. Salah satu Tutorial berjilbab (kiri di internet, kanan di mall)}

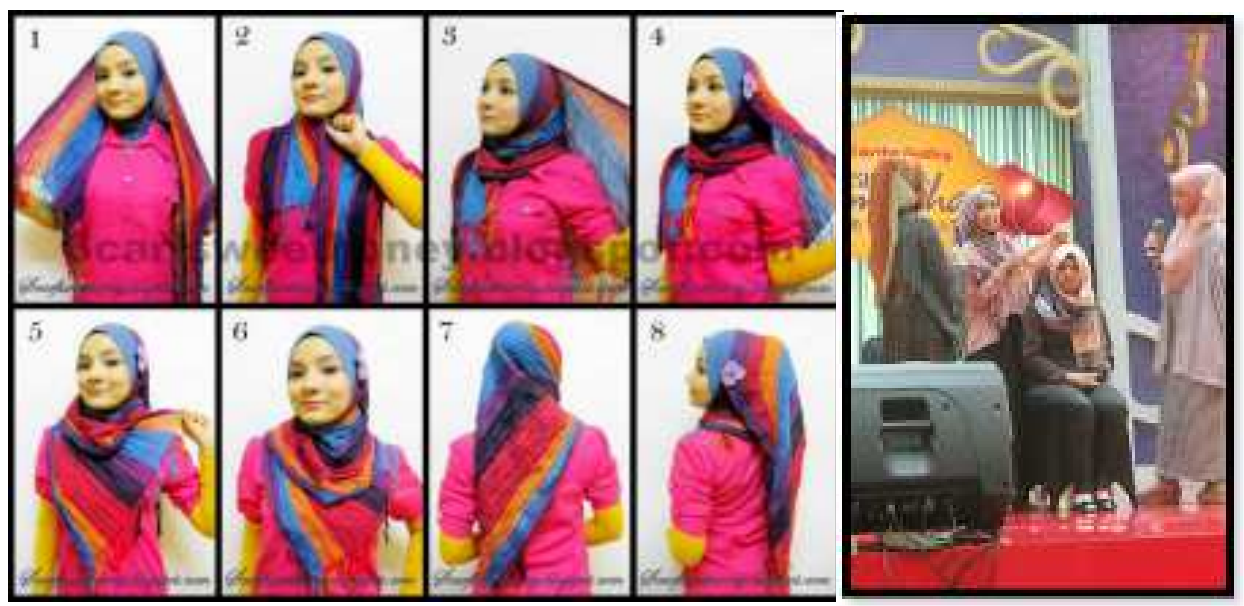

Sumber:http://rickafitria.files.wordpress.com/2012/02/mayang-style.jpg dan http://hijabcommunityuai.blogspot.com/

Jilbab juga digunakan dalam acara-acara keagamaan yang bersifat temporer, misalnya saat bulan Ramadhan. Para pramuniaga di mall selama bulan Ramadhan bekerja dengan mengenakan jilbab. Para pembawa acara di televisi tidak ketinggalan berjilbab. Para artis yang menyanyikan lagu-lagu religi tidaklah lengkap bila tidak menggunakan jilbab. Peragaan busana muslim diselenggarakan di banyak tempat, misalnya di hotel-hotel dan mall. Jadi, penggunaan jilbab dan busana muslim menandai sesuatu peristiwa penting keagamaan. Selain itu, jilbab juga digunakan untuk menandai peristiwa-peristiwa tertentu dalam kehidupan sehari-hari, misalnya: digunakan saat melayat seseorang yang meninggal dunia, menghadiri syukuran seseorang yang akan berangkat menunaikan ibadah haji, atau menghadiri pengajian saat seseorang merayakan sesuatu. Dengan demikian, jilbab secara temporer dikenakan untuk menandai peristiwa-peristiwa yang ada kaitan dengan unsur-unsur keagamaan. 
Jilbab juga menjadi ikon "islami" dalam berbagai wujud. Dapat dicontohkan misalnya karya sastra islami. Yang dimaksud islami di ini adalah tokohtokohnya beragama Islam, menggunakan pilihan kata atau diksi dari bahasa Arab yang biasa diucapkan oleh orang Islam. Dalam sampul depan karya sastra yang dilabeli "Islami" tokoh perempuannya seperti "diharuskan" berjilbab. Begitu pun dalam majalah-majalah "Islami". Model sampul depan yang umumnya perempuan, didandani dengan menggunakan jilbab. Dalam hal ini jilbab dijadikan komoditas untuk pelabelan.

\section{Gb. 5 Sampul Novel "Islami"}
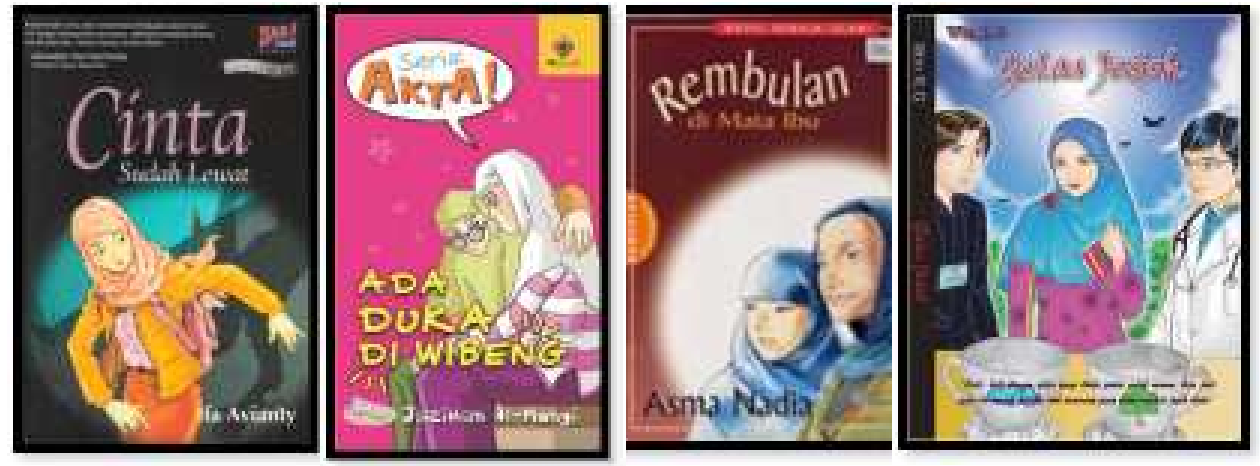

Penjelasan di atas telah mendudukkan jilbab sebagai salah satu budaya populer di Indonesia. Jilbab bukan hanya sekadar identitas muslim di Indonesia, melainkan tampil dalam berbagai wajah dan kepentingan. Seperti yang dikemukakan Storey (2007:4) dengan kata lain, teks budaya, misalnya tidak sekadar merefleksikan sejarah. Teks budaya membuat sejarah dan merupakan hasil dari pelbagai proses dan praktiknya, dan, oleh karena itu, seharusnya dikaji karena pekerjaan (ideologis) yang dilakukan (Storey, 2007:4). Bila ditempatkan dalam penjelasan Storey, teks budaya adalah jilbab yang punya sejarah perjuangan yang berliku di Indonesia. Namun kini, jilbab punya peran ideologis yang bermacam-macam seperti sudah dipaparkan di atas.

\section{Jilbab dalam Kerangka Semiotik: Identitas Hibrid}

Barthes dalam Petualangan Semiologi (2007) menjelaskan beberapa perspektif semiologis. Dia mengurutkan beberapa hal yang dapat dimaknai di ant aranya (1) lague, parole, dan ilmu-ilmu humaniora, (2) pakaian, (3) makanan, (4) mobil, perabotan, (5) beberapa sistem yang kompleks, (6) problemaproblema: asal-usul sistem, dan (7) problema-problema: hubungan langue/ parole. Secara khusus Barthes memandang penting fashion dijadikan kajian. Oleh sebab itu, khusus fashion dibuat buku sendiri dengan judul The Fashion 
system. Barthes memperlakukan fashion sebagai sebuah sistem tanda seperti model liguistik. Barthes adalah pengikut Saussurean yang berpandangan bahwa sebuah sistem tanda mencerminkan masyarakatnya. Tanda-tanda dapat dimaknai untuk kemudian dikomunikasikan. Dengan kata lain, fashion adalah tanda dan tanda menyampaikan pesan untuk dikomunikasikan.

Barthes (1983:3-5) membedakan tipe-tipe busana menjadi tiga, yaitu (1) image clothing, busana yang ditampilkan dalam fotografi atau gambar, (2) written clothing, busana yang dideskripsikan secara tertulis at au diterjemahkan dalam bahasa, (3) real clothing, busana sesungguhnya yang dikenakan manusia. Melalui pendekatan semiotik ini, jilbab akan dimaknai sebagai image clothing (citra yang ditampilkan oleh busana) dan real clothing (busana yang dikenakan dalam aktivitas sesungguhnya). Jilbab sebagai tanda dalam kerangka Saussure selalu mengacu pada dua bidang, yaitu penanda (bentuk) dan petanda (makna). Penanda sesuatu yang kasat mata, fisik, dan material sementara petanda adalah makna yang diacu penanda. Dengan demikian, jilbab adalah tanda, berbagai model jilbab dan cara menggunakannya adalah penanda, dan sesuatu yang dikomunikasikan melalui itu semua (makna) menjadi petanda. Kedua hal ini tentu sulit berdiri sendiri-sendiri.

Berkait dengan meluasnya pemakaian jilbab sebagai busana muslim di Indonesia dikemukakan Ibrahim (2011:xii) sebagai berikut:

Pada akhir 1980-an dan awaL 90-an ketika jilbabisasi merambah keluarga kelas menengah-atas, berbondong-bondonglah anak dan istri pejabat dan pengusaha yang mengenakan jilbab. Sejak itu, busana muslim menjadi trendi dan mencapai jilbab mulai mencapai prestise tertentu, mungkin mengomunikasikan hasrat menjadi orang modern yang saleh dan sekaligus menjadi muslim yang modern.... Jilbabisasi justru dianggap merupakan suatu tanda globalisasi, suatu lambang identifikasi orang Islam di Indonesia dengan umat Islam di negara-negara lain di dunia modern.

Pendapat Ibrahim di atas menunjukkan bahwa jilbab bukanlah budaya asli Indonesia. Kehadirannya karena globalisasi. Pendapat ini pun diperkuat dengan mengutip Andree Feillard bahwa konsep jilbab dan kain yang menutup seluruh badan sebelum tahun 1980-an merupakan sebuah konsep asing di dalam konteks masyarakat Indonesia. Sementara, bagi Susan Brenner kata jilbab secara umum dipahami sebagai sebuah gaya baru berbusana muslim para perempuan muda yang mulai populer pada tahun 1990-an sedikit banyak dipengaruhi oleh budaya Timur-Tengah. Ini berbeda dengan sarung tradisional, kebaya dan kerudung yang biasanya dipakai oleh perempuan Indonesia yang lebih tua. 
Apapun namanya, pemakaian tutup kepala yang kini disebut 'jilbab' bukanlah sesuatu yang khas dan original dari tradisi masyarakat Indonesia.

Jika jilbab dianggap bukan budaya asli Indonesia, melainkan dipengaruhi oleh budaya Timur Tengah, lalu bagaimana jilbab bermetamorfosis hingga menjadi pakaian "nasional" wanita muslim Indonesia sekarang. Saya akan menceritakan pengalaman pribadi ketika harus memakai busana muslim saat ada kegiatan bebas di sekolah (SMP tahun 1983). Artinya, saat itu tidak memakai seragam sekolah, tapi tetap mengharuskan berkerudung. Saya memakai baju kurung pinjaman dari ibu dan memakai celana jeans. Ketika hadir di sekolah, teman-teman mengejek bahwa saya koboi berkerudung. Artinya, pada saat itu tidaklah lazim wanita berkerudung memadankan kerudung dengan celana jeans. Lantas apa yang dianggap lazim pada saat itu?Model busana yang biasa dikenakan dengan kerudung adalah baju kurung dengan rok sebagaimana pakaian nasional wanita Malaysia atau seperti pakaian yang digunakan oleh para wanita di Sumatera Barat. Kondisi ini perlahan berubah seiring dengan maraknya budaya populer lewat televisi dan majalah.

Kerudung atau jilbab yang dikenakan saat itu pun tidak beragam. Kain putih segi empat yang dilipat menjadi segitiga dikenakan menutupi seluruh rambut dan disematkan peniti pada bagian dekat leher. Warna kerudung tidak banyak. Terbatas hanya warna hitam, cream, coklat, dan biru muda. Tidak begitu lazim juga menggunakan jilbab berwarna terang atau bermotif macammacam. Pemakai jilbab terus berkembang. Sebagai ilustrasi, teman seangkatan saya di Jurusan Sastra Indonesia Universit as Padjadjaran Bandung berjumlah 30 orang dan 20 di antaranya adalah perempuan. Pada tahun pertama berkuliah (1989) tidak ada satu pun yang berkerudung. Semester kedua mulai 2 berkerudung dan terus bertambah hingga saat kelulusan tinggallah 4 orang yang belum berkerudung. Apa yang terjadi di ruang kuliah kami juga merupakan representasi dari yang terjadi di luar sana. Namun, pada awal tahun 90-an pun model kerudung dan busana muslim pun belum bervariasi. Tidak ada outlet apalagi butik yang menjual khusus busana muslim. Namun, pada saat itu temanteman sudah lazim memadankan kerudung dan celana jeans.

Para pemakai jilbab awal tahun 80 -an akan saya sebut sebagai gelombang I. ${ }^{4}$ Mereka merupakan para perintis dan pendobrak apalagi mereka yang menggunakannya saat duduk di sekolah menengah. Mereka mengetahui risiko yang akan dihadapi yaitu dikeluarkan dan harus hijrah ke sekolah yang menerima

${ }^{4}$ Penyebutan ini terinspirasi pada gerakan feminisme di belahan dunia Barat. 
mereka. Eksodus yang mereka lakukan cukup mencengangkan. Mereka berasal dari sekolah negeri yang kualitasnya baik dan pindah ke sekolah-sekolah swasta dengan kualitas lebih rendah. Saat itu belum bermunculan sekolah umum berbasis agama dengan kualitas yang baik. Jilbab pada saat itu menjadi simbol keberanian dan perlawanan, sekaligus juga simbol kesalehan. Saya ingat "slogan" mereka saat itu "lebih baik hijrah untuk mempertahankan aqidah". Keberanian mereka melawan at uran penguasa, keputusan untuk pindah sekolah, keberanian untuk berbeda dengan kebanyakan adalah bentuk militansi para pemakai jilbab gelombang I ini. Hal ini dipertegas oleh pendapat Ibrahim (2011b: xi) bahwa sebelumnya kerudung atau jilbab, misalnya hanya dipakai di kalangan terbatas segelintir keluarga aktivis Islam, dan pelajar muslim di pesantren atau di sekolah umum sebagai ungkapan kepatuhan pada ajaran agama dan perlawanan terhadap status quo.

Selanjutnya pada dekade 90-an akan disebut sebagai gelombang II. Mereka tidak lagi melawan status quo karena pelarangan pemakaian jilbab sudah tidak diberlakukan lagi. Artinya, mereka bebas berjilbab di mana pun walaupun ada pekerjaan-pekerjaan tertentu yang masih belum memperkenankan karyawannya berjilbab. Kebebasan ini memunculkan berbagai kecenderungan. Yang paling menonjol adalah bermunculannya kelompok "Islam baru". Kelompokkelompok ini mempunyai pandangan yang berbeda-beda tentang cara berjilbab hingga melahirkan cara pakai yang berbeda pula. Tentang hal ini Barnard (2011: 95) memaparkan bahwa busana dan pakaian bisa menunjukkan keanggotaan atau afiliasi pada kelompok atau jamaah kelompok agama tertentu. Busana dan pakaian pun menandakan status atau posisi di dalam kelompok atau jamaah tersebut, dan menunjukkan kekuatan atau kedalaman keyakinan atau tingkat partisipasi. Pandangan Barnard di atas bukanlah khusus pada jilbab, tetapi pada pakaian -yang berkaitan kondisi magis-religius - secara universal. Namun, pandangan tersebut juga sejalan dengan pemakaian jilbab di Indonesia. Ada kelompok-kelompok tertentu yang menggunakan pakaian dan jilbab dengan sangat longgar, berwarna hitam, kadang-kadang bercadar seperti kebanyakan muslim di Yaman atau Afganistan. Ada pula kelompok-kelompok yang berkeyakinan tidak menggunakan celana panjang apalagi jeans, dan lain-lain.

Dengan demikian, ada nilai sosial dan status baru yang kemudian hadir bersamaan dengan munculnya banyak wanita muslim berjilbab. Barnard (2011) lebih jauh menjelaskan bahwa pakaian sering digunakan untuk menunjukkan nilai sosial atau status, dan orang kerap membuat penilaian terhadap nilai sosial atau status orang lain berdasarkan apa yang dipakai orang tersebut. Dalam 
kaitan maraknya pemakaian jilbab, saya tidak menyebut jilbab sebagai ekspresi individualistik karena saya menganggap bahwa ekspresi individualistik sejalan dengan ekspresi pribadi dalam berpakaian atau berdandan. Misalnya seseorang yang berjilbab dengan kerap menggunakan topi di balik jilbab itu merupakan ekspresi individualistik. Namun, pemakaian jilbabnya merupakan ekspresi sosial walau dalam pemilihan model dan motif sangatlah individual. Para pemakai jilbab gelombang II ini model dan gayanya sudah jauh lebih beragam. Mereka tidak hanya terpaku pada baju kurung, tetapi sudah lebih berani memadu-padankan berbagai gaya berbusana. Ini juga tidak lepas dari peran media. Di TV, majalah, dan koran mulai ditampilkan ragam busana muslim. Artis-artis yang menggunakan busana muslim, para desainer busana muslim, dan juga bagaimana berbusana muslim untuk aktivitas sehari-hari.

Tahun 2000-an sampai sekarang boleh dikatakan "periode jilbabers". Saya akan menyebutnya sebagai jilbab Gelombang ke-3. Gelombang ini boleh jadi merupakan "booming" jilbabers Indonesia. Periode ini semacam terjadi ledakan pemakai jilbab di Indonesia. Jumlah pemakainya meningkat berlipat-lipat diiringi dengan model dan trend yang berkembang pesat. Khusus untuk model jilbab juga seiring sejalan dengan perkembangan model pada umumnya. Bila trend menggunakan celana skiny, hal yang sama juga berlaku untuk mereka yang berjilbab juga sering jilbab mempunyai trend-nya sendiri. Misalnya, trend menggunaan jilbab yang dibentuk seperti sanggul tinggi. St. Sunardi dalam pengantar buku Strinari $(2007$; xv) menjelaskan mengapa trend menjadi semacam ikatan solidaritas:

...barang konsumsi (komoditi) mempunyai kedudukan yang penting untuk hadir dalam masyarakat, untuk mengintegrasikan seseorang dalam masyarakat. Rasa yang kurang lebih sama menjadi ikatan sosial, barang konsumsi menjadi semacam kartu identitas sosial .... Walaupun pembentukan masyarakat tergantung pada barang komoditi, ikatan sosialnya cukup dkuat karena barang-barang itu sudah difetiskan (nilai fungsional, tanda, dan simbolik bercampur baur.

Salah satu trend gaya berjilbab adalah jilbab sanggul, yaitu membuat model jilbab seperti sanggul seperti tampak pada gambar di bawah ini. 


\section{Gb. 6 Aneka gaya jilbab sanggul}

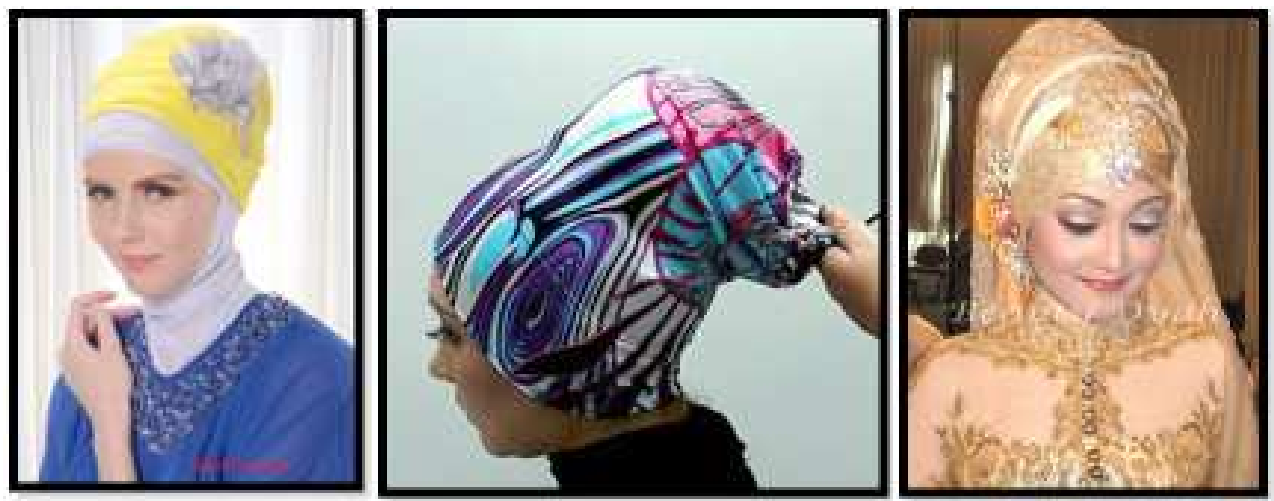

Sumber: http://miemiequf4.blogspot.com/

http://www.szlihin.com/2010/08/apa-hukum-bersanggul-tinggi.html

http://beautydyah.blogspot.com/2011/11/seminar-harpi-melati-jakarta.html

Jilbab sanggul ini mengadopsi berbusana perempuan tradisional Indonesia. Sanggul adalah hiasan yang dipakai di kepala yang digunakan bersama-sama dengan kebaya. Para wanita berjilbab juga memadankan baju muslim dengan jilbab mirip sanggul yang menjadi trend beberapa tahun belakangan ini. Mereka yang tidak memiliki rambut untuk dijadikan sanggul dapat dengan mudah mendapatkan sanggul tiruan di toko busana muslim. Trend ini juga masih dirasakan sampai saat ini.

Selain jilbab sanggul, trend pemakaian kain-kain etnik Indonesia dari berbagai daerah. Ini sejalan dengan trend fashion pada umumnya kemudian diadopsi oleh para perancang busana muslim. Misalnya beragam batik, berbagai kain tenun, jumputan, dan lain-lain menjadi trend busana muslim di Indonesia. Di bawah ini gambar peragaan busana muslim dengan memanfaatkan kain tradisional Indonesia.

\section{Gb. 7. Busana muslim memakai kain tradisional Indonesia}
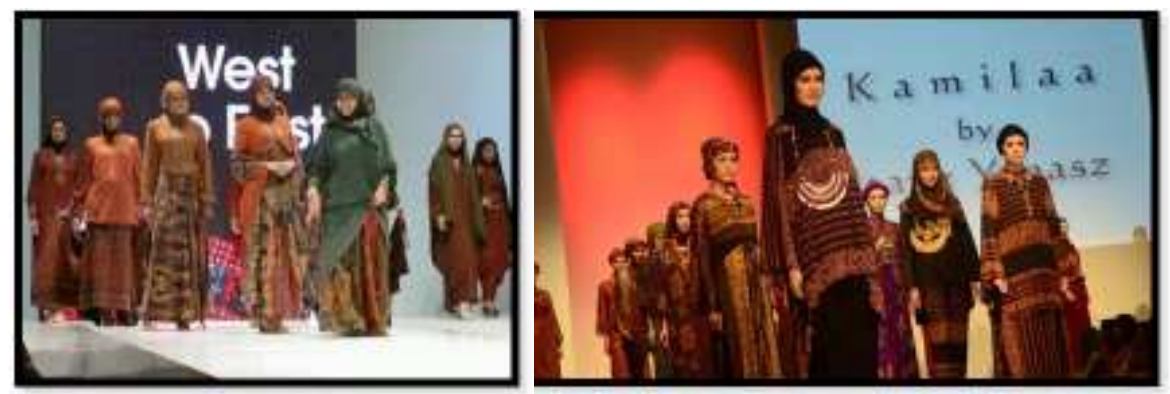

Sumber: http://m.kabar24.com/gaya-hidup/read/20140217/34/211257/tips-memilihbusana-hijab-dengan-kain-etnik http://trenfashion.org/jakarta-islamic-fashion-week-2013-5/ 
Di samping memanfaatkan kekayaan lokal untuk diadopsi dalam busana muslim, khazanah kekayaan busana dari negara lain juga menjadi trend. Salah satu contohnya adalah kaftan yang menjadi trend sebagai busana muslim di Indonesia pada tiga tahun belakangan ini. Seperti diketahui, kaftan adalah baju panjang longgar yang panjangnya sampai pergelangan kaki. Kaftan biasanya terbuat dari wol, kasmir, sutra, atau katun, dan dapat dipakai dengan selempang baik oleh lak-laki maupun perempuan. Kaftan adalah pakaian kuno asal Mesopotamia. Ini merupakan varian dari jubah atau tunik yang juga dikenal di berbagai belahan dunia selama ribuan tahun. Kaftan juga terkait dengan budaya Islam. Kaftan sering dipakai sebagai jubah di pengadilan; juga menunjukkan status sosial pemakainya. Kaftan diadaptasi menjadi pakaian muslim di Indonesia. Kepopuleran kaftan juga didukung oleh para selebritas Indonesia yang ramai-ramai memakai kaftan hingga terkenallah model kaftan Syahrini, Kaftan Arsyanti, dan lain-lain. Di bawah ini trend kaftan sebagai busana muslim.

\section{Gb. 8 Kaftan: trend busana muslim tahun 2012-2013}

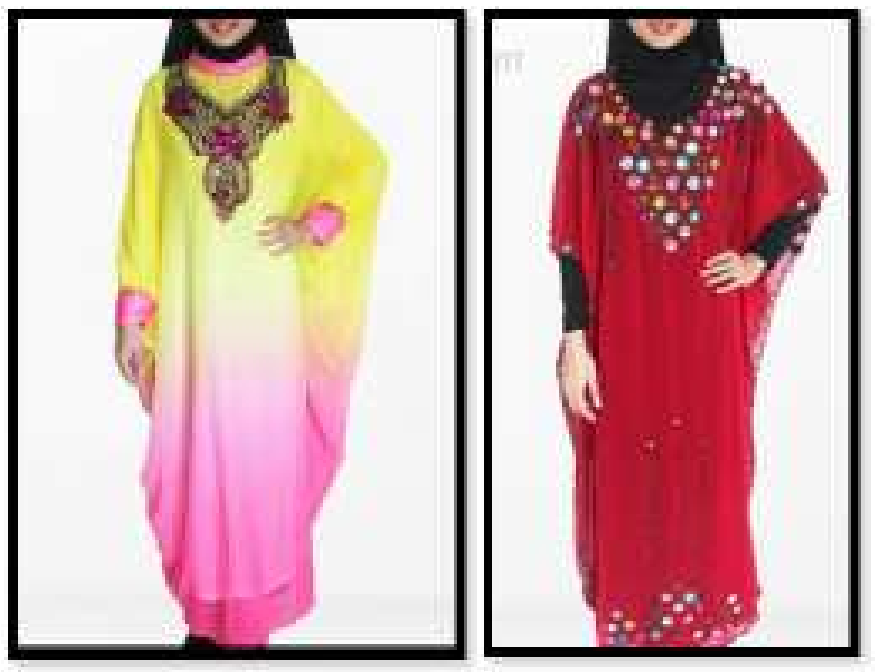

Sumber: http://sg.88db.com/Fashion/Women-s-Apparel/ad-3996202/

Dari penjelasan di atas telah terjadi silang budaya yang tecermin dalam busana muslim di Indonesia. Dapat diambil kesimpulan bahwa trend busana muslim di Indonesia terinspirasi dari berbagai budaya, baik budaya Indonesia ataupun budaya dunia. Hal ini boleh dikatakan bahwa identitas busana muslim di Indonesia adalah identitas hibrid. Dalam konteks ini, faktor-faktor lokal, regional, dan global berpadu. Dengan demikian, identitas yang ditampilkan muslim Indonesia adalah identitas hibrid yang memadukan berbagai unsur kebudayaan. 


\section{Jilbab: Sebuah Ambivalensi}

Barnard (2011:75) menyebutkan bahwa hal-hal yang berkenaan dan berkaitan dengan kesopanan merupakan alasan utama untuk mengenakan pakaian. Argumen untuk kesopanan beredar di seputar ide bahwa bagian tubuh tertentu adalah tak senonoh dan memalukan dan hendaknya ditutupi sehingga tidak kelihatan. Maka menyembunyikan tubuh melalui sarana pakaian jadi berasosiasi dengan hasrat menghindari rasa berdosa dan malu. Mengenakan jilbab dan busana muslim bukan sekadar kesopanan, melainkan juga keyakinan dan ketaatan pada ajaran agama.

Para pemakai jilbab sering dihadapkan pada pilihan yang saya pikir cukup sulit. Dalam konteks Indonesia, budaya sudah mengakar cukup kuat, sementara agama Islam masuk kemudian. Mereka berusaha mengawinkan budaya yang sudah ada dengan pemakaian jilbab tersebut. Misalnya dalam upacara pernikahan. Di satu sisi pengantin ingin tetap mempertahankan pemakaian jilbab, tetapi di sisi lain mereka juga ingin memasukkan unsur budaya lokal yang boleh jadi "mengharuskan" menggunakan beragam hiasan kepala atau busana yang cukup tipis dan ketat. Pada akhirnya, mereka bernegosiasi dengan kondisi ini dan mengambil jalan tengah dengan mengawinkan keduanya. Di bawah ini akan dicontohkan beberapa gambar hasil negosiasi tersebut.

\section{Gb. 9. Menegosiasikan Kebaya: Kain tipis dilapisi dalaman sewarna kulit}

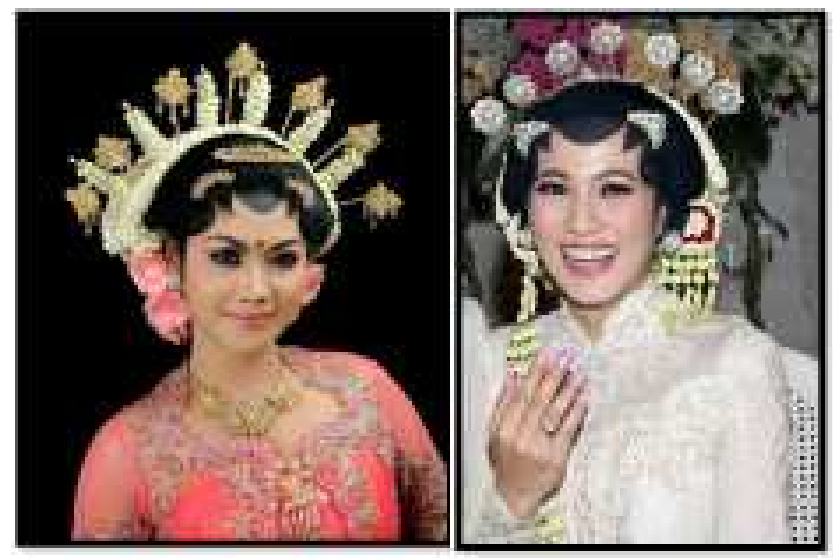

Sumber: entangwanita.com/mode/memilih-kebaya-muslim-modern-untukpengantin.html http://rinysuwardy.com/home/34-kebaya-pengantin-muslim-2.html 

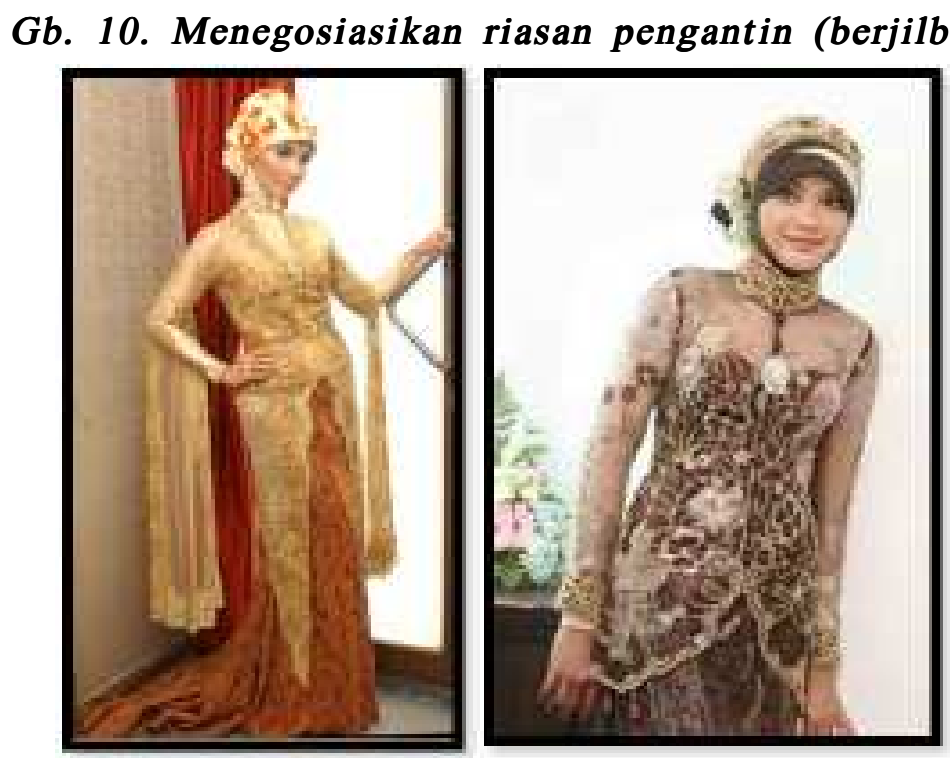

Sumber: http://www.tempo.co/read/beritafoto/15061/Pernikahan-Dude-Harlino-danAlyssa-Soebandono

http://album-wedding.blogspot.com/2013/10/photo-pengantin-adat-solo.html

Gambar-gambar di atas merupakan bentuk negosiasi sekaligus ambivalensi. Mereka ingin tetap menggunakan jilbab sebagai bentuk kepatuhan, tetapi ada "kepatuhan" yang lain tetap dilanggengkan. Kondisi yang sama juga terjadi pada busana dinas di kantor-kantor pemerintahan yang mengharuskan mereka berseragam. Jilbab langsung dinegosiasikan dengan seragam dinas. Mereka yang berjilbab dan tidak berjilbab tidak tampak ada perbedaan dalam hal busana. Jadi, yang membedakan hanya dalam pemakaian jilbab. Di bawah ini gambar baju dinas bupati dan baju dinas polisi wanita.

\section{Gb. 11 Baju dinas bupati (kanan berjilbab)}

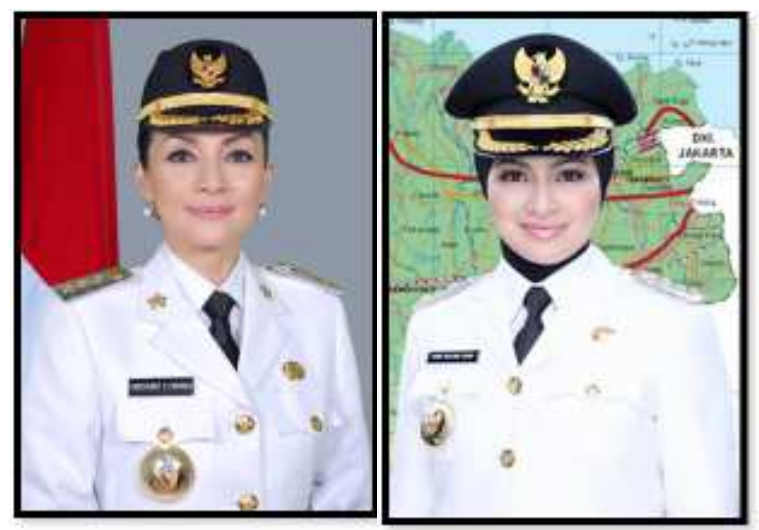

http://www.infonews.web.id/2012/10/profile-biodata-foto-bupati-dan.html 
Gb. 12 Baju dinas polisi wanita (kanan berjilbab)
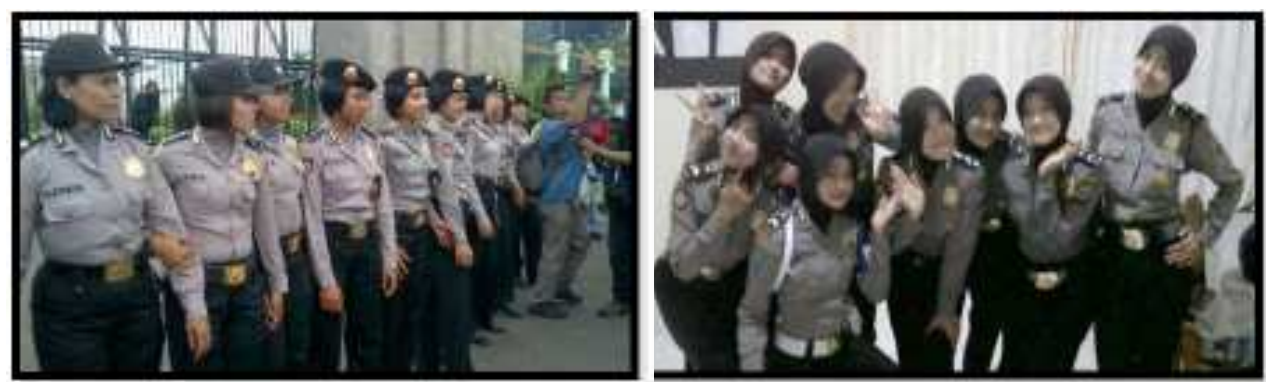

http://metro.news.viva.co.id/news/read/300214-polwan-dijadikan-pagarhidup-di-depan-dpr

http://kabarwashliyah.com/2013/06/15/ipw-polwan-layak-berjilbab/

\section{E. Simpulan}

Keberadaannya jilbab selalu menarik untuk diperbincangkan karena berjalin berbagai unsur di dalamnya. Unsur-unsur itu sulit untuk diurai satu per satu sebagai sesuatu yang mandiri karena di dalamnya saling berkelindan dan punya hubung kait dengan yang lain. Sedikitnya ada tiga simpulan yang bisa ditarik dalam tulisan ini: (1) jilbab sekarang merupakan salah satu budaya populer di Indonesia, (2) Identitas yang ditampilkan adalah identitas hibrid, dan (3) para pengguna jilbab dihadapkan pada negosiasi budaya sekaligus ambivalensi.

\section{Daftar Pustaka}

Barnard, Malcolm. 2011. Fashion sebagai Komunikasi: Cara Mengomunikasikan Identitas Sosial, Seksual, Kelas, dan Gender. Yogyakarta: Jalasutra.

Barthes, Roland. 1983. The Fashion Sistem. New York: Hill and Wang.

Barthes, Roland. 2007. Petualangan Semiologi. Yogyakarta: Pustaka Pelajar. Candraningrum, Dewi. 2013. Negotiating Women's Veiling: Politics and Sexuality in Contempotary Indonesia. Bangkok, Thailand: Irasec.

Chaney, David. 1996. Lifestyles: Sebuah Pengantar Komprehensif. Yogyakarta: Jalasutra.

El Guindi, Fadwal. 20013. Jilbab: Antara Kesalehan, Kesopanan, dan Perlawanan. Jakarta: Serambi.

Hadi, Solichul. 2006. Jilbab Funky tapi Syar'i. Yogyakarta: Diwan.

Hamdani, Deny. 2011. Anatomy of Muslim Veils: Practice, Discourse and Changing Appearance of Indonesian Women. LAMBERT Academic Publishing. 
Hardiyanti, Rima. 2012. "Komunitas Jilbab Kontemporer "Hijabers" di Kota Makasar". Skripsi. Fakultas Ilmu Sosial dan Ilmu Politik. Universitas Hasanudin. Makasar. (tidak dipublikasikan).

Heryanto, Ariel (ed). 2012. Budaya Populer di Indonesia: Mencairnya Identitas Pasca-Orde Baru. Yogyakarta: Jalasutra.

Ibrahim, Idi Subandy. 2011a. Budaya Populer sebagai Komunikasi: Dinamika Popscape dan Mediascape di Indonesia Kontemporer. Yogyakarta: Jalasutra.

Ibrahim, Idi Subandy. 2011b. "Pakaian Anda Menunjukkan Siapa Anda? Semiotika Fashion sebagai Komunikasi Artifaktual" dalam Fashion sebagai Komunikasi. Yogyakarta: Jalasutra.

Prasetia, Heru. 2009. "Pakaian, Gaya, dan Identitas Perempuan Islam”. Jurnal Srinthil Edisi 17. Depok.

Raleigh, Elizabeth. 2004. "Busana Muslim dan Kebudayaan Populer di Indonesia: Pengaruh dan Persepsi”. Skripsi Universitas Muhamadyah Malang. (tidak dipublikasikan).

Strinati, Dominic. 2007. Populer Culture: Pengantar Menuju Teori Budaya Populer. Yogyakarta: Jejak.

Storey, John. 2007. Cultural Studies dan Kajian Budaya Pop: Pengantar Komprehensif Teori dan Metode. Yogyakarta: Jalasutra.

Zoest, Aart van. 1993. Semiotika: Tentang Tanda, Cara Kerjanya dan Apa yang Kita Lakukan Dengannya. Jakarta: Yayasan Sumber Agung. 